Cinémas

Revue d'études cinématographiques

Journal of Film Studies

\title{
The Subway Grate Scene in The Seven Year Itch: "The Staging of an Appearance-As-Disappearance”
}

\section{Graham Smith}

Volume 14, numéro 2-3, printemps 2004

Histoires croisées des images. Objets et méthodes

URI : https://id.erudit.org/iderudit/026010ar

DOI : https://doi.org/10.7202/026010ar

Aller au sommaire du numéro

Éditeur(s)

Cinémas

ISSN

1181-6945 (imprimé)

1705-6500 (numérique)

Découvrir la revue

Citer cet article

Smith, G. (2004). The Subway Grate Scene in The Seven Year Itch: "The Staging of an Appearance-As-Disappearance”. Cinémas, 14(2-3), 213-244.

https://doi.org/10.7202/026010ar
Résumé de l'article

La scène de la bouche de métro, dans The Seven Year Itch, est placée dans un contexte qui produit un « montage des attractions " projetant un éclairage nouveau sur les clichés légendaires de Marilyn Monroe. Un regard rétrospectif sur des films antérieurs rattache ces images à l'histoire du cinéma, alors que l'établissement de rapports prospectifs avec des films plus récents montre leur évidente modernité. Le fascinant dévoilement des dessous féminins est aussi un topos littéraire. Les écrits de Freud sur la sexualité expliquent les raisons de cette obsession, alors que ceux de Barthes, qui souligne le caractère érotique de l'intermittence, mettent en évidence les différences entre

l'apparition/disparition au cinéma ou en littérature et le traitement de phénomènes similaires par les photographes. 


\section{The Subway Grate Scene in The Seven Year Itch: "The Staging of an Appearance-As-Disappearance" ${ }^{1}$}

\section{Graham Smith}

\section{RÉSUMÉ}

La scène de la bouche de métro, dans The Seven Year Itch, est placée dans un contexte qui produit un «montage des attractions" projetant un éclairage nouveau sur les clichés légendaires de Marilyn Monroe. Un regard rétrospectif sur des films antérieurs rattache ces images à l'histoire du cinéma, alors que l'établissement de rapports prospectifs avec des films plus récents montre leur évidente modernité. Le fascinant dévoilement des dessous féminins est aussi un topos littéraire. Les écrits de Freud sur la sexualité expliquent les raisons de cette obsession, alors que ceux de Barthes, qui souligne le caractère érotique de l'intermittence, mettent en évidence les différences entre l'apparition/disparition au cinéma ou en littérature et le traitement de phénomènes similaires par les photographes.

\section{ABSTRACT}

The subway grate scene in The Seven Year Itch is placed in context, creating a "montage of attractions" that illuminates the iconic images of Marilyn Monroe. Parallels in earlier films situate these images in cinematic history, while later references to them demonstrate their continuing modernity. The "wondrous revealment" of women's undergarments is also a common theme in literature. Freud's writings on sexuality explain this preoccupation, while Barthes's focus upon the erotic character of "intermittence" points to fundamental differences between "appearance-as-disappearance" in cinema and literature and the treatment of similar subjects by still photographers. 
Is not the most erotic portion of a body where the garment gapes? . . . it is intermittence, as psychoanalysis has rightly stated, which is erotic: the intermittence of skin flashing between two articles of clothing (trousers and sweater), between two edges (the open-necked shirt, the glove and the sleeve); it is this flash itself which seduces, or rather: the staging of an appearance-as-disappearance.

Barthes 1975

The first glimpse already prepares the apotheosis; in convulsive expectation, the philosophers spot the choice morsels and squint at them with dilated eyes and blazing pupils.

Queneau 1988

Billy Wilder's adaptation of George Axelrod's play The Seven Year Itch: A Romantic Comedy was, in September 1954, the vehicle for staging a series of memorable "intermittences" or "appearances-as-disappearances" - to approximate Roland Barthes's terms-involving Marilyn Monroe in the role of "The Girl." These scenes generated huge publicity for Wilder's film and became known worldwide when, on 1 June 1955, Monroe's twenty-ninth birthday, The Seven Year Itch had its première in New York.

The action of Axelrod's highly popular play, which opened in November 1952 at the Fulton Theatre in New York, is set entirely in Richard Sherman's apartment in the Gramercy Park section of New York City. By contrast, Wilder's film roams around the city, with scenes taking place in Grand Central Station, in Sherman's office, and, most notably, outside the Trans-Lux Theater at Lexington Avenue and 52nd Street. Wilder originally shot the Trans-Lux Theater scene on location in New York in the early hours of the morning of 15 September 
1954. In take after take, Monroe was photographed standing over a subway grating with her full-skirted summer dress billowing above her waist to reveal her legs and underpants (figures 1 and 2). ${ }^{2}$ The original caption to figure 1 elaborated somewhat coyly:

Scene outside a food store at 51st Street and Lexington Avenue early today as Marilyn Monroe stood over a subway grating and had her skirts blown up by a giant blower while talking to Tom Ewell in a scene from the movie they're making of the famed stage play "SevenYear Itch.” About 1,500 stay-up-late New Yorkers formed an audience, very appreciative, too, as the synthetic breeze unveiled the Monroe legs and nylon whatchamacallits.

The type of full skirt worn by Monroe was first introduced in February 1948 by the French couturier Christian Dior (figure 3) as a reaction against the austerity of war-time patterns. The extravagant skirts of Dior's "Carolle Line" (from "corolla" mean-

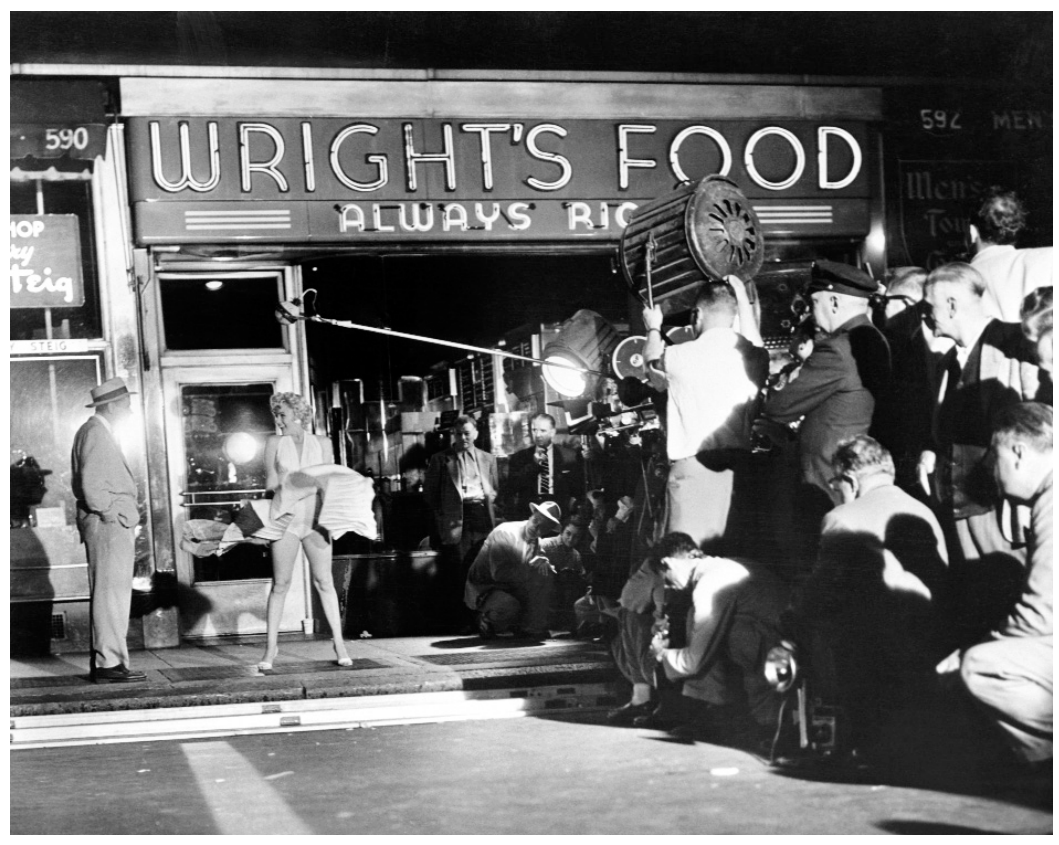

Figure 1. Marilyn Monroe and Tom Ewell Filming "The Seven Year Itch" (16 September 1954). U1264471INP RM @ Bettmann/CORBIS

The Subway Grate Scene in The Seven Year Itch: "The Staging of an Appearance-As-Disappearance" 


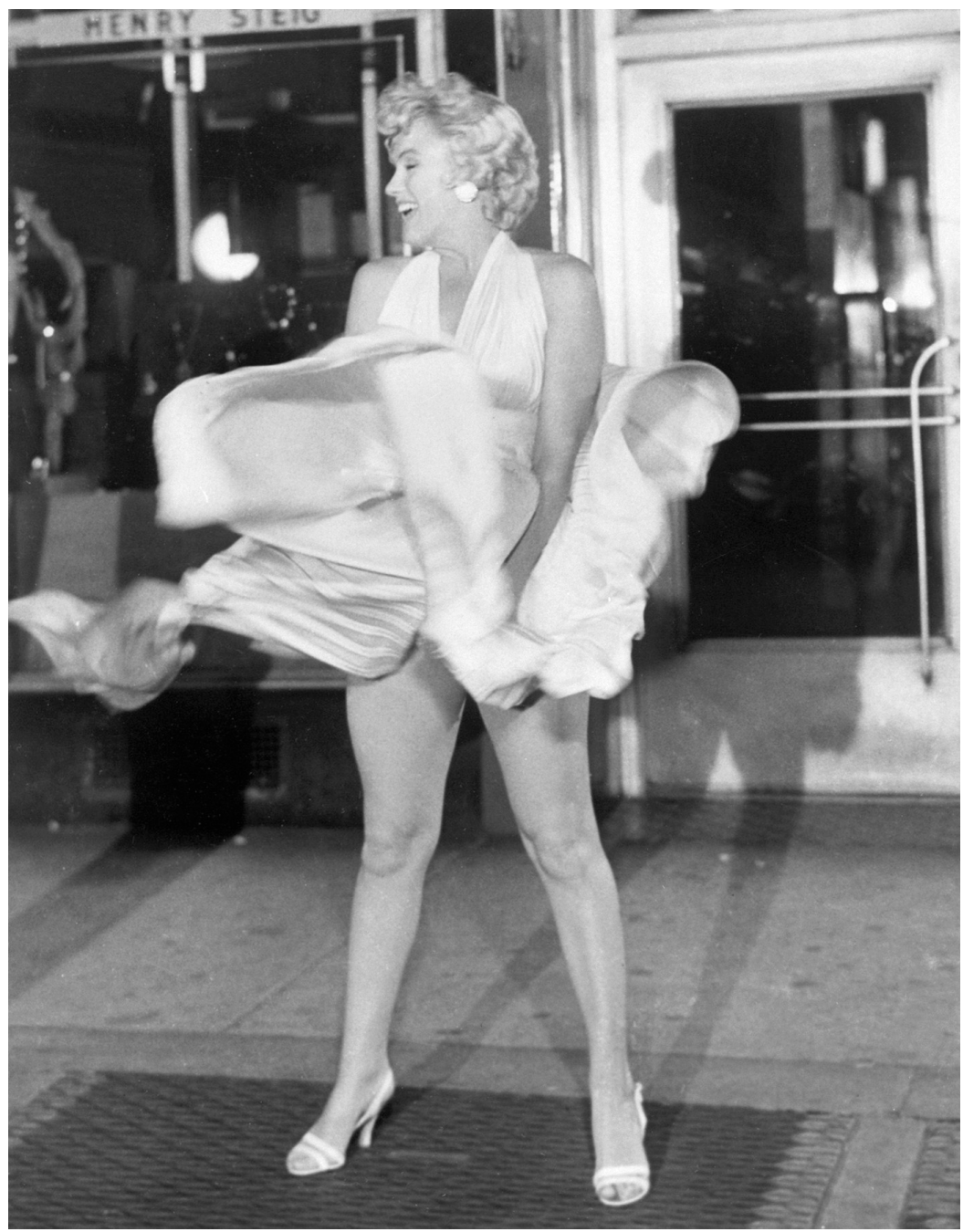

Figure 2. Marilyn Monroe on Subway Grating for "The Seven Year Itch" (16 September 1954). BE037457 RM @ Bettmann/CORBIS

ing "the petals of a flower, typically forming a whorl enclosing [appropriately] the sexual organs") required as much as twelve metres of material and were meant to be worn with matching or contrasting sheer stockings in order to create a style that was at once elegant, feminine and provocative. The original caption to the photograph reproduced here explained: 


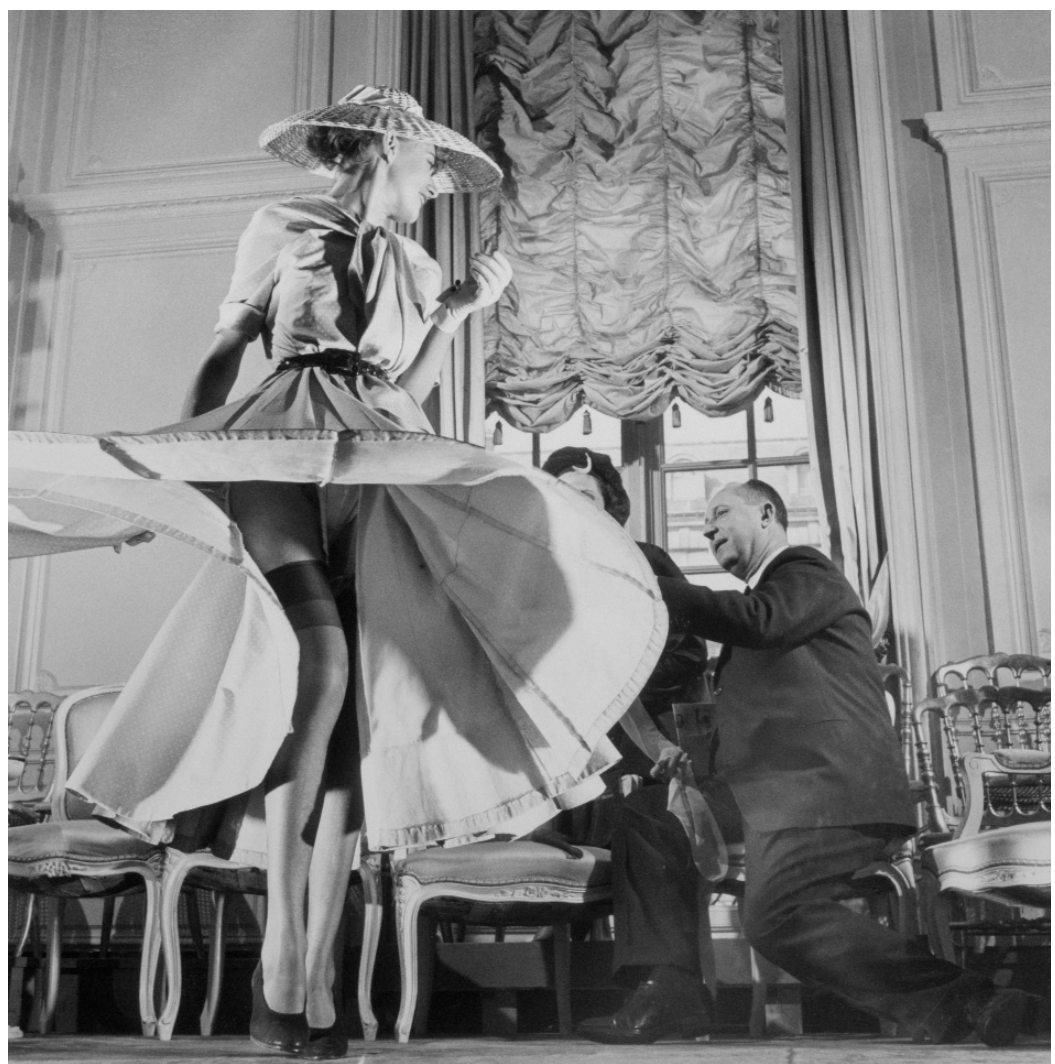

Figure 3. Christian Dior with Woman Modeling Dress and Stockings (11 March 1948). U864177ACMEI RMI C Bettmann/CORBIS

Stockings were highlighted for the first time when Christian Dior, noted French designer, exhibited his French collection. The hose, which either continued the dress' color scheme from hem to ankles or afforded a direct contrast, ranged in shades from tender peach to ink black. The colors are called "Boulevard Banquet." Here a model swirls the skirt of a light blue crêpe dress to feature the sheer navy blue stockings.

Christened the "New Look" by American journalists, democratic versions of this style remained popular well into the 1950s, as is evident from Monroe's dress.

In fact, the scenes outside the Trans-Lux Theater caused a near riot among the New Yorkers who attended the shoot. They may also have contributed to the breakdown of Monroe's

The Subway Grate Scene in The Seven Year Itch: "The Staging of an Appearance-As-Disappearance" 
marriage, for Joe DiMaggio was incensed by the "convulsive expectation"- to borrow Raymond Queneau's phrase-of the spectators and by Monroe's exhibitionism. ${ }^{3}$ To put this in Freudian terms, Monroe's abandon and the public's voyeurism both overstepped contemporary standards of decorum. Freud had proposed in his Three Essays on the Theory of Sexuality, first published in 1905, that it was "[the] progressive concealment of the body which goes along with civilization [that] keeps sexual curiosity awake" and that "curiosity seeks to complete the sexual object by revealing its hidden parts" (Freud 1991, p. 69). Conversely, the contemporary philosopher and legal scholar, Thomas Nagel, has recently argued that concealment is an essential component of decorum and that the exercise of restraint, particularly with regard to a person's clothing, is central to civilized interaction among men and women. ${ }^{4}$ In the end, the New York footage for The Seven Year Itch proved to be unusable, and the scene had to be shot again on the Fox lot in Hollywood. Nevertheless, the location shots in New York contributed to the film's huge success, which was in certain respects a succès de scandale, for the absent scenes gave the film a frisson of explicit sexuality that was beyond the reach of the Hayes Office. $^{5}$

The scene outside the Trans-Lux Theater is treated decorously in the film. When Monroe as The Girl stands over the subway grating waiting for the first train and then for the express, the camera cuts away to focus upon her dress and legs. When the rush of air from the subway lifts Monroe's skirt, her legs in effect are detached from her person and become abstracted and disembodied. ${ }^{6}$ Most importantly, Monroe's underpants are not shown. As a result, the overtly sexual character of the location shots is neutralized. Nevertheless, the colossal twenty-five-foot billboard that was installed in Times Square over Loew's State Theater for the première of The Seven Year Itch was a full-length image of Monroe with her dress billowing around her to reveal a glimpse of her underpants (figure 4). A Movietone "sneak" preview of the film focused upon this billboard and zeroed in on the "appearance," lingering erotically on the patterned border of Monroe's panties. In a sense, the teasing relationship between 
the billboard and the film was itself a form of appearance-as-disappearance. $^{7}$

\section{Adaptations and Variations}

These images of Marilyn Monroe with her dress billowing around her immediately acquired iconic status and have inspired many adaptations and variations in the fifty years since they were taken.

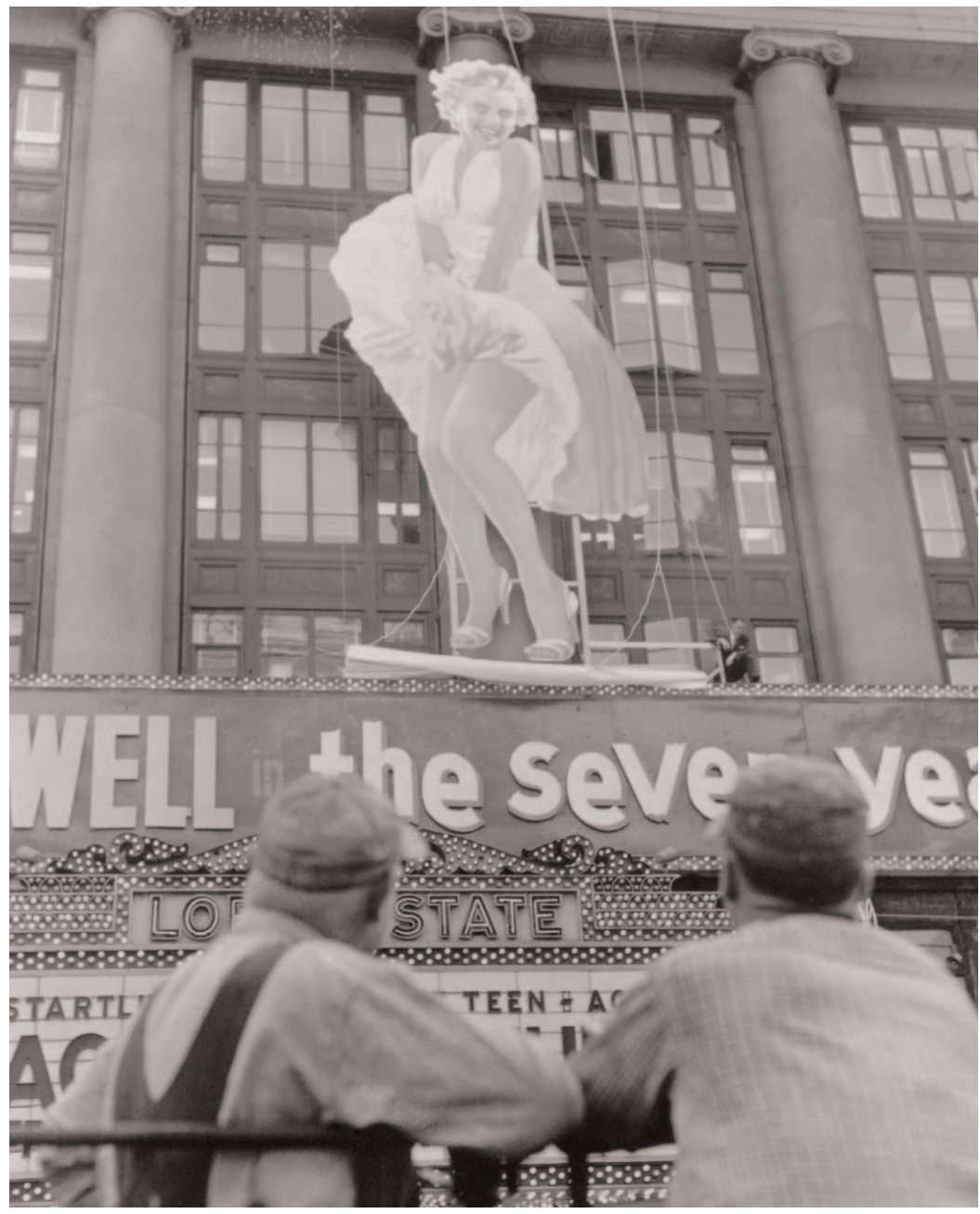

Figure 4. Fifty-Two Foot Figure of Marilyn Monroe Installed at Loew's State Theater, New York (19 May 1955). U1084468 RM @) Bettmann/CORBIS

The Subway Grate Scene in The Seven Year Itch: "The Staging of an Appearance-As-Disappearance" 219 
The year after Twentieth Century-Fox released The Seven Year Itch, for instance, one of the promotional images for the film was appropriated in London to represent a vision of the future, for a life-size cut-out of Monroe formed part of an installation that Richard Hamilton, John McHale and John Voelcker made for This is Tomorrow, an exhibition held at the Whitechapel Art Gallery. In this seminal exhibition, which was in effect a visual manifesto for a British Futurism, a giant figure of Robby the Robot from Forbidden Planet, which MGM had released on 1 August 1956, loomed over the cutout of Marilyn Monroe. The New World of the USA and the still unexplored worlds of outer space were therefore juxtaposed. Almost exactly a year later, on 6 October 1957, the Soviets launched the first Sputnik. It is no exaggeration to say that the image of Monroe signified the beginning of an equally far-reaching program of British exploration into the art and culture of modern America.

Films from the 1970s, 1980s and 1990s that make reference to Monroe's scene for The Seven Year Itch include, in chronological order, Ken Russell's Tommy, Gene Wilder's The Woman in Red, Nicolas Roeg's Insignificance, and Quentin Tarantino's Pulp Fiction. It is noteworthy that all these films recall the billboard images and posters for The Seven Year Itch rather than the film itself. Near the beginning of the rock opera Tommy, which was released twenty years after The Seven Year Itch, there is a scene at "Bernie's Holiday Camp" showing a "Lovely Legs Competition" of the kind that was popular in the 1940s and 1950s. In order properly to focus upon the legs and perhaps also to enable the women decorously to display them to best advantage, only the legs of the competitors are visible to the viewers. This device is not unlike Wilder's solution to the problem in The Seven Year Itch, when he framed Monroe's legs in such a way as to disconnect them from her person. A little later in Tommy, Russell stages a complex and elaborately choreographed healing ceremony, in which Marilyn Monroe is elevated to the status of a holy icon. A giant plaster sculpture of the star replaces the traditional image of the Madonna, while the blind file past her and touch her garment. When, at the end of this scene, Tommy and his 
mother pay homage to this tawdry sculpture, it falls backwards and explodes into fragments.

Gene Wilder's The Woman in Red, which was released in 1984, echoes more generally the theme of The Seven Year Itch. The central character has been married for seven years but becomes intoxicated by a beautiful young woman, who teases him to the brink of adultery. In almost the first scene of The Woman in Red, this woman performs a dance over an air vent in an underground parking structure, allowing her red dress to billow up over her head to reveal impossibly long legs, red shoes and matching red panties. The allusion to The Seven Year Itch is quite clear, but the scene also provides a dazzling visual illustration of the degree to which body-exposure in a mainstream film had become acceptable in the intervening thirty years. Nicolas Roeg's 1985 Insignificance, adapted from a play by Terry Johnson, records what Albert Einstein and Marilyn Monroe might have done had they met in a New York hotel room immediately after Monroe filmed the subway scene. By contrast, Quentin Tarantino's 1994 reference in Pulp Fiction to The Seven Year Itch is overtly nostalgic in character. Tarantino includes a Marilyn Monroe look-alike as part of the ambience of Jack Rabbit Slim's 1950s pop diner, the setting for an early scene in the film. In this instance, the quotation from The Seven Year Itch is generally in keeping with the fastidiously retro character of the setting.

Other appropriations of the billowing skirt motif include a sweet photograph entitled Barcelonetta, taken in 1988 by Dona Ann McAdams. This shows two little girls, like miniature Marilyns - one still reliant on her pacifier-with their summer dresses ballooning about them like levitating bells; the younger of the two children insouciantly displays her knickers. ${ }^{8}$ A sumptuous picture made in 1990 by the contemporary US photographer Laurie Simmons offers a sophisticated variation on the trope. Simmons's photograph (figure 5) shows a chorus line of three petit-fours "dressed" in pleated paper cups. ' Supporting the paper cups and their chocolates, each of which is crowned by a single nipple, are long tapered legs, exposed almost full length, much like Monroe's in The Seven Year Itch. As a conse- 
quence of this visual association, the paper cups metamorphose into pleated dresses. The contemporary Japanese photographic artist Yasumasa Morimura has likewise created variations upon the subway images in his actress series, portraying himself as Monroe in the 1996 photographs Self-Portrait (actress) after Black Marilyn and Self-Portrait (actress) after White Marilyn. ${ }^{10}$ The wit of McAdams's, Simmons's, and Morimura's photographs depends in large part on the viewer's being able to catch the references they make to Marilyn Monroe. Not only would they not exist without their precedents, but the pleasure we derive from them would be incomplete if we were unaware of this allusion. ${ }^{11}$

The subway motif has become ubiquitous on both sides of the Atlantic in recent years. On 9 May 2003, shortly before Wimbledon, tennis player Anna Kournikova parodied Marilyn Monroe in a photograph that was printed in The Times of London. Likewise, a controversial advertisement for a new express rail service to Brussels, reported and reproduced in The Guardian on 4 October 2003, superimposed the head of Queen Elizabeth II on Monroe's body. Still more recently the image of Monroe was translated into a photograph of a kilted Highlander that was reproduced as a full-page advertisement in The New York Times on 6 April 2004 to promote Tartan Day in New York City.

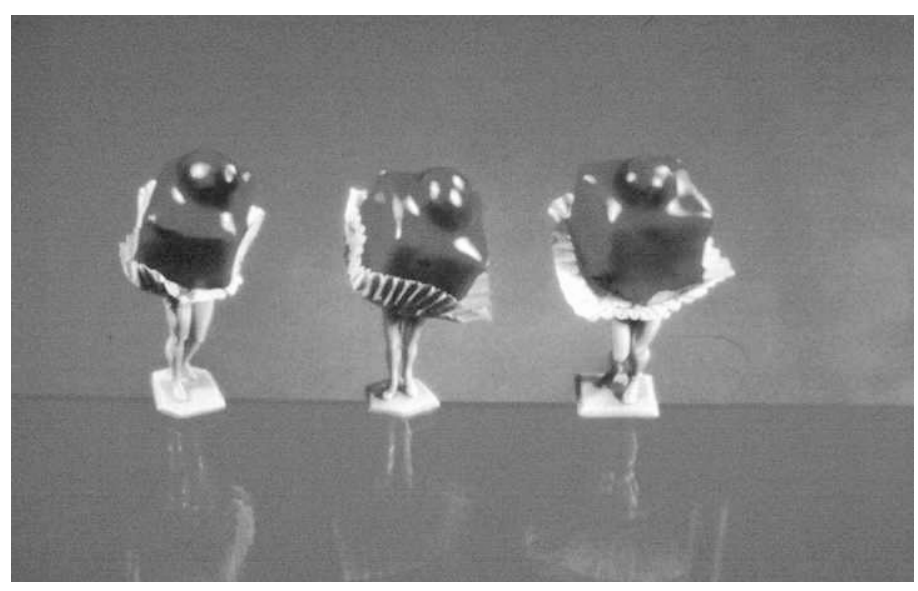

Figure 5. Laurie Simmons, Three Red Petit-Fours, silver dye bleach process print (1990). (C) Laurie Simmons 
Monroe's status as an icon has evidently become so universal that all these variations on the billowing skirt motif could be created with confidence that viewers everywhere would recognise the reference. However, it was also the case that Marilyn Monroe exemplified an era that was naturally coming to an end. Although the cinched waists and full skirts that originated with the "New Look" remained popular for much of the 1950s, this feminine, elegant fashion was soon to be replaced by Mary Quant's androgynous Pop style of mini skirts and coloured tights. ${ }^{12}$ If "progressive concealment . . . keeps sexual curiosity awake," as Freud suggested, then the 1960s taste for exposure neutralized the erotic charge that had been released in the preceding decade by the "intermittence of skin flashing between two articles of clothing."

\section{An Anterior Discourse}

Although the image of Marilyn Monroe with her dress blowing up around her has become a venerable international icon, it also has a place in what Susan Sontag has termed a "discourse anterior to itself." 13 In "Tradition and the Individual Talent," an influential essay published in 1920 in The Sacred Wood, T. S. Eliot famously wrote:

No poet, no artist of any art [my italics], has his complete meaning alone. His significance, his appreciation is the appreciation of his relation to the dead poets and artists. You cannot value him alone; you must set him, for contrast and comparison, among the dead. . . . The existing monuments form an ideal order among themselves, which is modified by the introduction of the new (the really new) work of art among them. The existing order is complete before the new work arrives; for order to persist after the supervention of novelty, the whole existing order must be, if ever so slightly, altered; and so the relations, proportions, values of each work of art toward the whole are readjusted; and this is conformity between the old and the new. Whoever has approved this idea of order . . . will not find it preposterous that the past should be altered by the present as much as the present is directed by the past. 
It is illuminating to consider the subway scene in The Seven Year Itch in the context of Sontag's and Eliot's ideas-and especially in relation to Eliot's credo that existing monuments form an order that is modified by the introduction among them of a new work. The image of Monroe standing with her dress blowing around was in fact introduced into a pre-existing cinematic order, and so, to paraphrase Eliot, this order was necessarily modified by Wilder's creation of this scene. In short, the past was altered by the present, while the present reflected upon the past. By building on a pre-existing order in cinematic history, Wilder simultaneously "contemporize[d] the historical and ... historicize[d] the contemporary." 14

An early instance of the billowing skirt motif in the history of cinema - of which Wilder certainly would have been awareoccurs at the beginning of Josef von Sternberg's masterpiece of 1930, Der blaue Engel, starring Emil Jannings and Marlene Dietrich. In the opening scene of the German-language version of the film, a group of students amuse themselves by blowing lightly upon a card of some kind. A few minutes later their teacher, Dr Immanuel Rath (Jannings), confiscates this card from the ringleader. The card's nature is still concealed from the viewer; only when we see Rath himself blowing gently on a carte-de-visite photograph of the cabaret singer Lola Lola is the fascinating novelty revealed. The professor's gentle puff lifts Lola's tutu, revealing an intoxicating glimpse of the tops of Dietrich's ivory thighs, black stockings, garters and frothy undergarments. This erotic epiphany is also the first step in Rath's terrible descent into decadence, madness and death.

A studio postcard of this type, showing Dietrich in her role as Lola Lola, was found among the star's personal effects in New York after her death in 1992 (figure 6), while a passage in "The Basque and Bijou" from Delta of Venus, erotica that Anaiis Nin wrote in the early 1940s, indicates that titillating postcards of this kind were not unusual at that time. In the final pages of her story, Nin writes suggestively that "[The Basque] had a postcard showing a dancer with a short feathery skirt. When he breathed on it, the skirt raised itself and the woman stood exposed. One of her legs was in the air, like a ballet dancer's, and the [boy] 


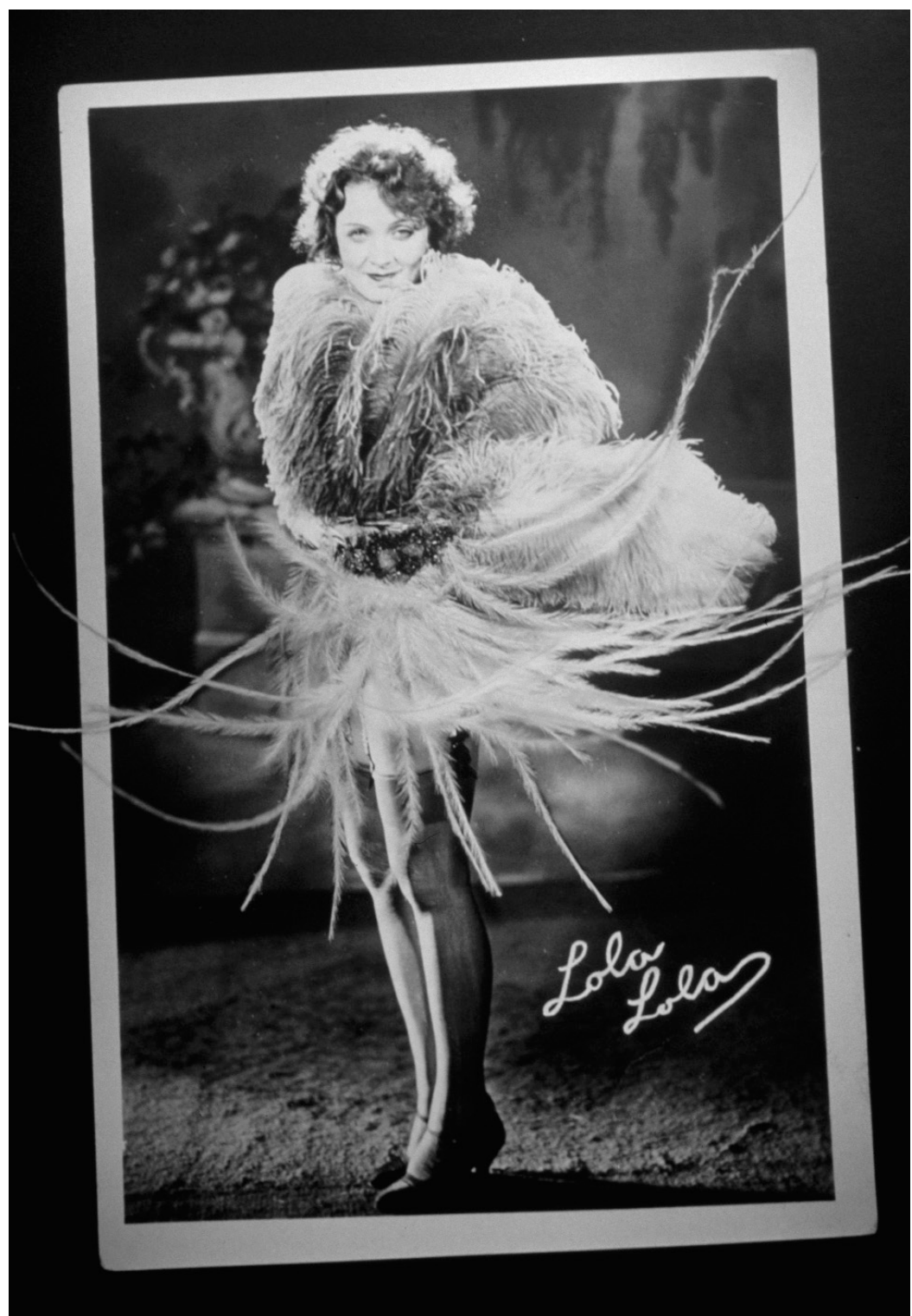

Figure 6. Marlene Dietrich as Lola Lola in "Der Blaue Engel," postcard from Marlene Dietrich's personal effects (1930). 0000289437-028 RM (C) MAIMAN RICK/CORBIS SYGMA

could see how she was made [my italics]." 15 Such cards may themselves be linked to the tradition of photographic flick books, Mutoscopes and Kinoras, mechanized forms of which

The Subway Grate Scene in The Seven Year Itch: "The Staging of an Appearance-As-Disappearance" 22) 
remained popular in amusement arcades into the 1940s and were significant elements in the early history of the motion picture. $^{16}$

Near the beginning of The Awful Truth, a 1937 comedy directed by Leo McCarey and starring Irene Dunn and Cary Grant as about-to-be-divorced Lucy and Jerry Warriner, there is a delicious scene set in a night club in which Lucy, Jerry and Daniel Leeson, Lucy's new beau from Oklahoma (Ralph Bellamy), watch the club "chanteuse," Dixie Lee Bell (played by Joyce Compton), perform "My Dreams are Gone with the Wind." At the end of each verse, on the line "My dreams are gone with the wind," a jet of wind blows Dixie Lee's dress above her head, exposing her knickers. The camera focuses in part on Dixie Lee's tawdry act, but as much attention is given to Lucy's, Jerry's and Daniel's diverse reactions to it, showing the latter's increasingly prurient interest in the performance. "That'd go great out West," he comments. Dixie Lee's song is evidently intended to parody Margaret Mitchell's Gone With the Wind, which had been published the year before, and it refers also to Harold Arlen's popular song, Stormy Weather, which Ethel Waters had introduced at the Cotton Club in 1933. It is also likely that McCarey intended the performance to recall Marlene Dietrich's act in The Blue Angel. In fact, the witty, allusive character of The Awful Truth is also self-referential. Near the end of the film, at the home of the parents of Jerry's new fiancée Barbara Vance, "madcap heiress" and New York socialite, Lucy herself parodies Dixie Lee Bell's performance. Masquerading as Jerry's Southern sister "Miss Lola Warriner"-another reference to Dietrich's character in The Blue Angel-and fortified by a tall bourbon and ginger ale, she performs a wonderful burlesque of Dixie Lee's act, interjecting "Woo-woo-woo! Get it?" at the end of each verse, when the wind machine should come into play. Lucille Ball played a similar role as "Bubbles" in the 1940 RKO Radio Pictures comedy Dance, Girl, Dance, directed by Dorothy Arzner. When, in her stage persona as "Tiger Lily," Ball performs her number "Mother, What Do I Do Now?" a strong wind gusts on stage, resulting in a burlesque strip-tease that prepares for Maureen O'Hara's entrance as the ballet-dancing "stooge."17 
The skirt scenes of the 1930s had precedents in popular films from the silent era such as "IT," a romantic comedy directed by Clarence Badger and Josef von Sternberg that was released by Paramount in 1927. Elinor Glyn's eponymous novel, which had established "It" as a synonym for sex appeal, was the point of departure for the film, in which Clara Bow played Betty Lou Spence, the original "It" girl. ${ }^{18}$ Betty Lou is a "vendeuse" who sells lingerie at Waltham's department store, a role that enables her to interact decorously with her middle-class customers while dreamily handling and modelling flimsy undergarments. The contradictory nature of her functions gives Betty Lou-and the "vendeuse" as a type-a somewhat ambiguous moral and social status. ${ }^{19}$

Early in the film, Betty Lou sets her sights on Cyrus Waltham, Jr., who inherited the business from his father. As a result of a wonderfully feminine campaign of enticement and entrapment, Betty Lou spends an evening with Waltham at Coney Island. The easy intimacy that results from riding the "social Mixer" reaches a climax on the helter-skelter, with Betty Lou's invitation, "Hold me tight, Mr Waltham." The twisting, tumbling slide provides several opportunities for the cameraman to shoot intimate views of Betty Lou's garters and undergarments (figure 7). At the end of the ride, Betty Lou and Waltham must pass through a short wind tunnel, which-for the moment the camera remains on her-blows Betty Lou's skirt high above her waist, providing a fleeting glimpse of her stockings, garters, and cami-knickers.

The scenes at Coney Island in "IT" had precursors in a threepart film, entitled Rube and Mandy at Steeplechase Park and Coney Island, made by the Edison Manufacturing Co. about 1903. In this film, which lasts a total of twelve minutes, Rube and Mandy try out a variety of rides and amusements, negotiating the rope bridge, riding the rattan slide and shooting the chute. The film ends with a shot of the couple eating frankfurters. ${ }^{20}$ However, a still earlier film made by Thomas $\mathrm{A}$. Edison, Inc. may be the ultimate prototype for the subway scene in The Seven Year Itch. Copyrighted in August 1901 and entitled What Happened on Twenty-third Street, New York City, 


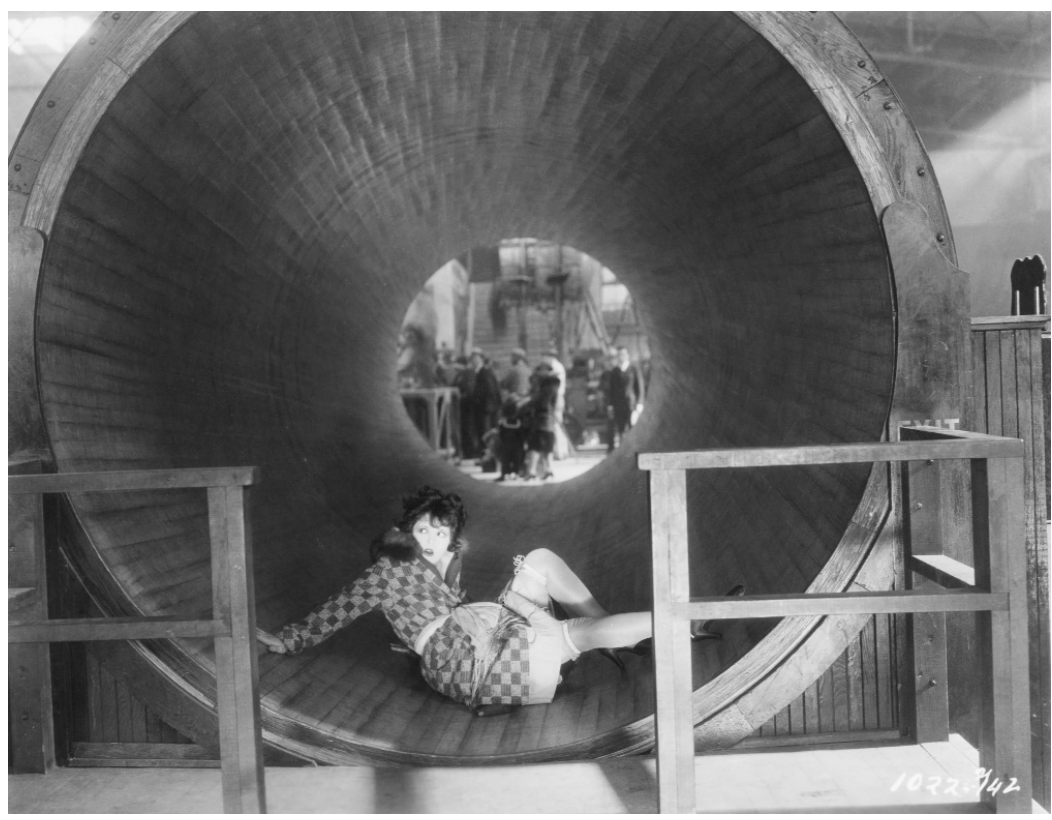

Figure 7. Clara Bow in "IT" (1927). JS1567841 (C) John Springer Collection/ CORBIS

this short film, which lasts a little over a minute, is summarized in a contemporary Edison catalogue:

This is a winner and sure to please [my italics]. The scene as suggested by the title is made on 23rd street, New York City. In front of one of the large newspaper offices on that thoroughfare is a hot air shaft through which immense volumes of air is forced by means of a blower. Ladies crossing these shafts often have their clothes slightly disarranged, (it may be said much to their discomfiture). As our picture was being made a young man escorting a young lady, to whom he was talking very earnestly, comes into view and walks slowly along until they stand directly over the air shaft. The young lady's skirts are suddenly raised to, you might say an unreasonable height, greatly to her horror and much to the amusement of the newsboys, bootblacks and passersby. This subject is a winner.

The camera gives a street-level view from the pavement looking along 23rd Street. The film begins with footage of pedestrians 


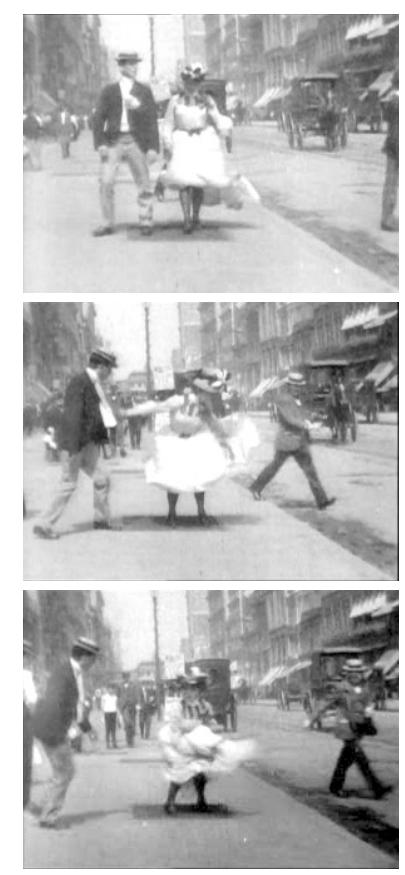

Figure 8. Thomas A. Edison, Inc., "What Happened on Twenty-third Street, New York City" (1901). Library of Congress Motion Picture, Broadcasting and Recorded Sound Division, Washington, D. C.

and street traffic before the actors - a man in summer clothes and a woman wearing an ankle-length dress-enter and walk toward the camera. They pause as they cross a grate on the pavement and the escaping air blows the woman's dress up to her knees (figure 8 ). ${ }^{21}$

I am not suggesting that these early films constitute a literal genealogy for the subway scene in The Seven Year Itch. My intention is rather to create a cinematic "montage of attractions," a centrifugal field similar to those in the great German cultural historian Aby Warburg's Mnemosyne, in order retrospectively to illuminate the iconic images of Monroe. ${ }^{22}$ Nor am I suggesting that Billy Wilder had all these films in mind when he created his scene, but it is surely the case that he had referred consciously to some at least of these earlier appearances-as-disappearances and that they had given him a visual and thematic authority for his scene. We can also be sure that Wilder had expected viewers to recognise these references. ${ }^{23}$ 


\section{Literary Counterparts}

Di wee ma [dear little mama], me's nearly driven myself quite wild today with drawing little Zipporah's chemisette-you never did see such a dear little wimplydimply, crinkly edge as it's got just across four inches under her chin — and it looks as if the least breeze would blow it loose-and di ma, me do so want to see what's inside it-me don't know fot to do. . . . I wish I could dream of seeing her with her clothes off-di ma. She would be only a "little brown girl"—for really—-there's more umber than anything else-in her colour, when one comes to paint it. (Ruskin, in Hilton 2000, p. 276)

In this remarkable passage, John Ruskin, Slade Professor of Fine Art at Oxford, author of Modern Painters and arbiter of Victorian taste, confesses to what Freud, in his essay "Infantile Sexuality," published in 1905, would term the scopophilic "instinct." ${ }^{25}$ What inspired Ruskin's ecstasy of excitement was evidently his hope that a slight breeze might reveal a seductive "flash" - to borrow the term employed by Barthes—of what lay beneath the "chemisette" worn by Zipporah, one of the daughters of Jethro in the fresco by Sandro Botticelli in the Sistine Chapel in Rome (figure 9). Ruskin's reaction to Zipporah reminds us that a beautiful woman can make even the wisest of men foolish. There was also a dark aspect to Ruskin's infatuation with Zipporah, however, for Ruskin, like Pygmalion, had a penchant for sculpted and painted women. ${ }^{26}$ That aside, it is not surprising that Botticelli's young woman should have mesmerized Ruskin, for Walter Pater's essay, "a Fragment on Sandro Botticelli," which became a pivotal element in the English rediscovery of Botticelli, had appeared in August 1870. ${ }^{27}$

Ruskin was not alone among his contemporaries in being fascinated by what lay inside women's dresses. In fact, the tone of a series of letters that Sir Edward Coley Burne-Jones wrote in the 1880s to Katie Lewis, the young daughter of the eminent solicitor Sir George Lewis, has a good deal in common with the teasing character of Ruskin's letter to Joan Severn. ${ }^{28}$ Katie was evidently a lively and strong willed child. Burne-Jones painted her portrait in 1886, when she was eight, and during the 1880s and 


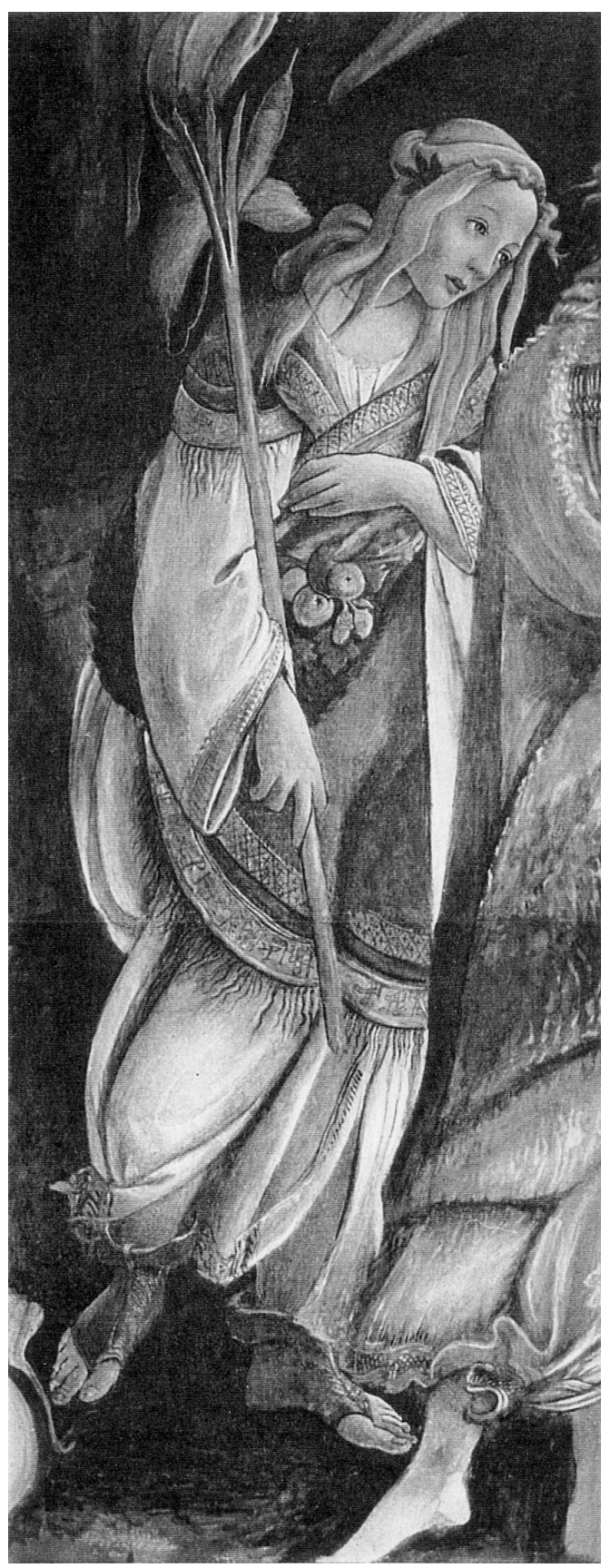

Figure 9. Zipporah, photogravure of a drawing by John Ruskin after Sandro Botticelli. Frontispiece to Val d'Arno, The Works of John Ruskin, E. T. Cook and A. Wedderburn (eds.) (1906).

The Subway Grate Scene in The Seven Year Itch: "The Staging of an Appearance-As-Disappearance" 231 
1890s he sent her numerous letters illustrated with drawings. Among these is a sequence of six in which Burne-Jones sought Katie's advice on how to dress a wayward doll named Matilda. We learn from the first of these that Burne-Jones had visited Katie when she was ill in bed and that he had been introduced to the little girl's doll_ “a most pleasing person." Burne-Jones had evidently committed a faux-pas when he met this doll, for he writes: "I have been very particular not to make my drawing rude. It isn't rude is it, dear." The letters play on Katie's embarrassment at the mention of underclothes, which Burne-Jones must have touched on in relation to her doll, and they describe Burne-Jones's inability to control Matilda's headstrong progress to a precocious sophistication. Burne-Jones's difficulties began when he discovered that the doll he had bought had "nasty leather bits," instead of being wax all over. In addition to having a frock and a sash, he asks in the second letter, "ought it to have dran [ers]-I mean ought it to have other things." "I cannot dress that doll," he confesses in the next letter:

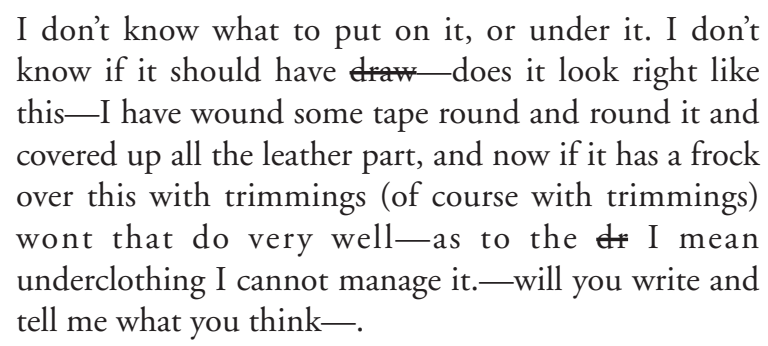

We learn next that Burne-Jones was forced in despair to send Matilda to be dressed by a "Madame Elise," whose premises were on Regent Street. From there, she came back "with a fanand long gloves with thirty buttons, and an improver and Valenciennes lace-and a lace p-tt-c-t and a tulle underskirt and a chimmie.'

Other European writers of the nineteenth century showed similar preoccupations with what lay under women's outer clothing. Émile Zola, for instance, published an erotic epic on the subject of women's "intimate wear," devoting several pages in the final chapter of $A u$ Bonheur des dames to Octave Mouret's Great White Sale. He began with the department devoted to 
corsets and bustles, "but after that came the attractive intimate wear, pieces of it scattered over the huge rooms as though a group of pretty girls had been undressing themselves from one department to the next down to the naked satin of their skins." There follows a breathless catalogue of item after item of feminine underwear. Finally, Zola (2001, pp. 399-400) concludes:

\begin{abstract}
[...] woman was dressed again, the white wave of this cascade of linen slipped behind the mystery of skirts . . . all this dead percale and dead muslin . . . was about to come alive with the life of the flesh, warm and redolent with the smell of love, a white cloud sanctified, bathed in night, the slightest flutter of which, to reveal the pink glimpse of a knee in the depths of this whiteness, would devastate the world.
\end{abstract}

Zola was concerned here to illustrate the new aggressive levels of consumerism encouraged by department stores such as Mouret's, but he wanted also to draw attention to the addictive and erotic nature of this new acquisitiveness.

If the exposure of women's undergarments became a common trope in film-making in the 1920s and 1930s, it is also central to one of the most erotic sections in James Joyce's Ulysses, which was first published in 1922. ${ }^{30}$ This episode takes place on Sandymount shore, where Gerty MacDowell, Cissy Caffrey and Edy Boardman have gathered, together with the Caffrey twins and the Boardman baby, "to have a cosy chat beside the sparkling waves and discuss matters feminine." MacDowell becomes conscious that Leopold Bloom is watching her, and so she initiates a distant, teasing courtship. A fireworks display provides the score for this seduction, and the individual fireworks function as accompaniment and metaphor for MacDowell's increasingly bold "revealment" of herself. In fact, the fireworks at once choreograph and mirror her mating dance, while also providing a wonderful visual metaphor for its climax.

"She leaned back far to look up where the fireworks were," Joyce observes, "and she caught her knee in her hands so as not to fall back looking up and there was no-one to see only him and her when she revealed all her graceful beautifully shaped legs like that, supply soft and delicately rounded." 
And she leaned back and the garters were blue to match on account of the transparent and they all saw it and shouted to look, look there it was, and she leaned back ever so far to see the fireworks and something queer was flying though the air, a soft thing to and fro, dark. And she saw a long Roman candle going up over the trees up, up, and, in the tense hush, they were all breathless with excitement as it went higher and higher and she had to lean back more and more to look up after it, high, high, almost out of sight, and her face was suffused with a divine, an entrancing flush from straining back and he could see her other things too, nainsook knickers, the fabric that caresses the skin, better than those other pettiwidth, the green, four and eleven, on account of being white and she let him and she saw that he saw and then it went so high it went out of sight a moment and she was trembling in every limb from being bent so far back he had a full view high above her knee no-one ever not even on the swing or wading and she wasn't ashamed and he wasn't either to look in that immodest way like that because he couldn't resist the sight of the wondrous revealment half offered like those skirtdancers behaving so immodest before gentlemen looking and he kept on looking, looking.

A Roman candle provides the climax to this passage when it bursts, shedding "greeny dewy stars falling with golden, $\mathrm{O}$ so lovely! O so soft, sweet, soft!"”

Raymond Queneau's popular novel Pierrot mon ami, gives particular insight into the seedy fairground culture that flourished in the 1940 s by catering to this fixation with women's undergarments. ${ }^{32}$ Queneau's book begins with Tortose, the operator of a "Palace of Fun" in an amusement park, instructing Pierrot on his responsibilities as a new employee:

"Well then you see," Tortose-Monsieur Tortosewent on, "you grab them when they get up to the cakewalk, you grab them by the wrists, you hold 'em tight, and then you plunk them down over the blowhole. How long you leave them there, that's a matter of tact, there's special cases, you just have to learn." 
The Palace of Fun is as much spectacle as experience. Spectators- "philosophers" as Queneau calls them-pay sixty sous, as compared with the twenty paid by the participants. For this they can watch the "maliciously calculated indignities that pursued the buffs' every step." "They were," however, "less interested in the ridiculousness of the louts than in the deshabille of the females." A current of air "blew up [a woman's] dress, and revealed two legs and some frillies: the delighted philosophers applauded."

One, following on behind, seeing the said misadventure and wishing to avoid it, refused to follow Petit-Pouce, who had gone back in search of victims, but he grabbed her. The audience roared approval. He pulled her along, a silence fell in expectation of the supreme indiscretion, and he deposited her on the allotted spot and held her longer that the other one, to secure the vengeance of the philosophers, who had been excited by the attempted refusal. A third was ardently awaited by the satyrs because the first blow hole had given them cause to hope for underwear reduced to a minimum.

That the skirt motif had roots in popular culture is confirmed by a contemporaneous photograph by the English photographer Kurt Hutton showing two young women on a fairground ride at Southend-on-Sea (figure 10). In this well-known picture, which Hutton took in 1938 for the popular British magazine Picture Post, one of the Southend "girls" rises in her seat and her skirt blows over the tops of her stockings to expose her suspenders, thighs and knickers. ${ }^{33}$

In 1951 Bert Hardy explored a similar theme in a carefully orchestrated "candid" snapshot that he too made on an assignment for Picture Post. Hardy's Maidens in Waiting (figure 11), taken with a "Brownie," shows two young women perched on iron railings overlooking the beach at the popular seaside resort of Blackpool. An impudent sea breeze is exploring the dress of the girl in the polka dot skirt. ${ }^{34}$ It is noteworthy that in Hardy's photograph, as in that by Hutton, the victim appears to have entered willingly into the game of exposure. If there is a wish to see what is concealed, there is also a willingness to expose what is normally kept hidden-particularly when one is at the seaside 


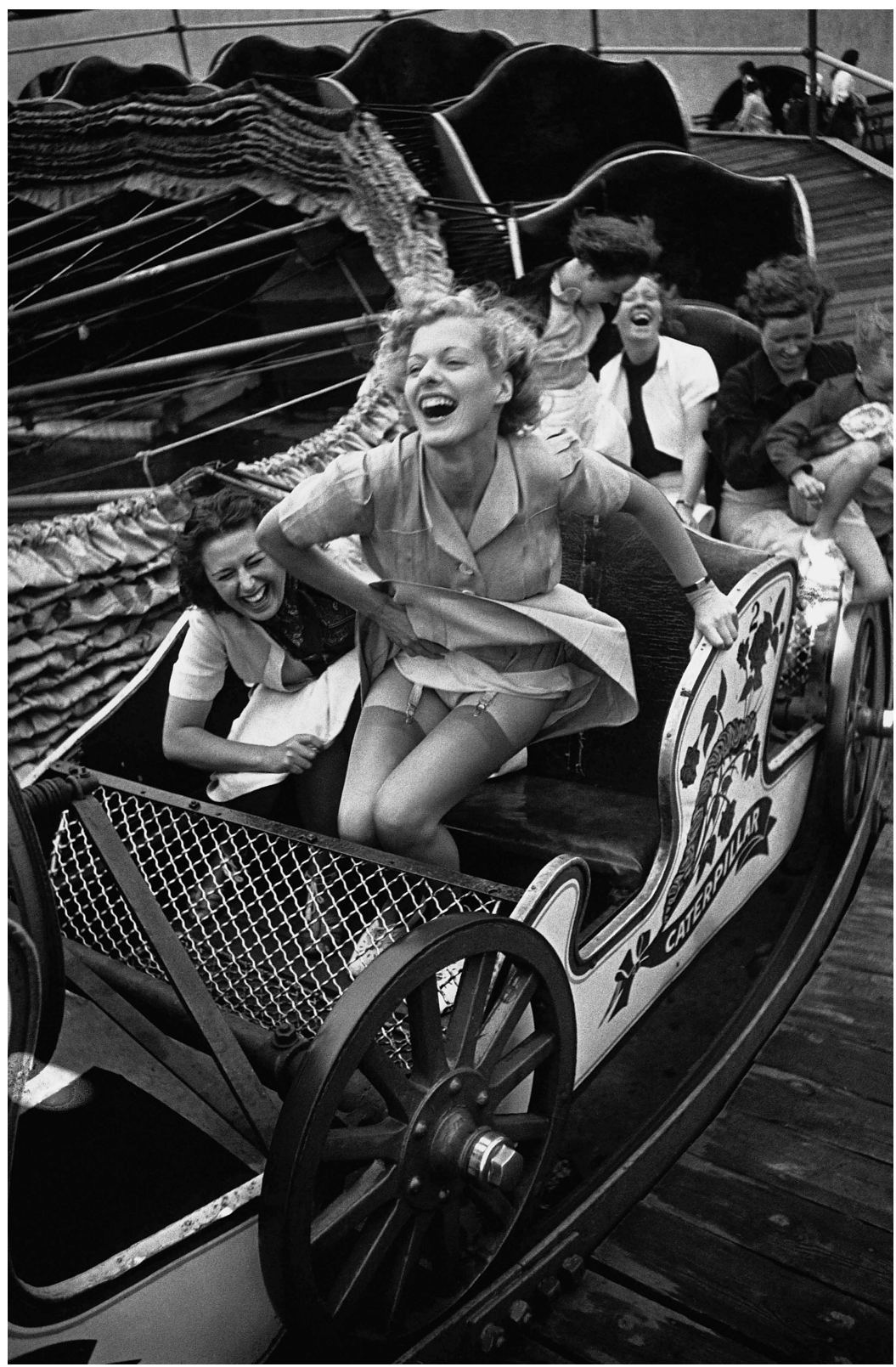

Figure 10. Kurt Hutton, Young Women at a Fair, silverprint (1938). HU010261 RM @ Kurt Hutton/Hulton-Deutsch Collection/CORBIS

or at a fair, in high spirits and among friends. There is evidently an element of the ritual of courtship in this voluntary exposure. 


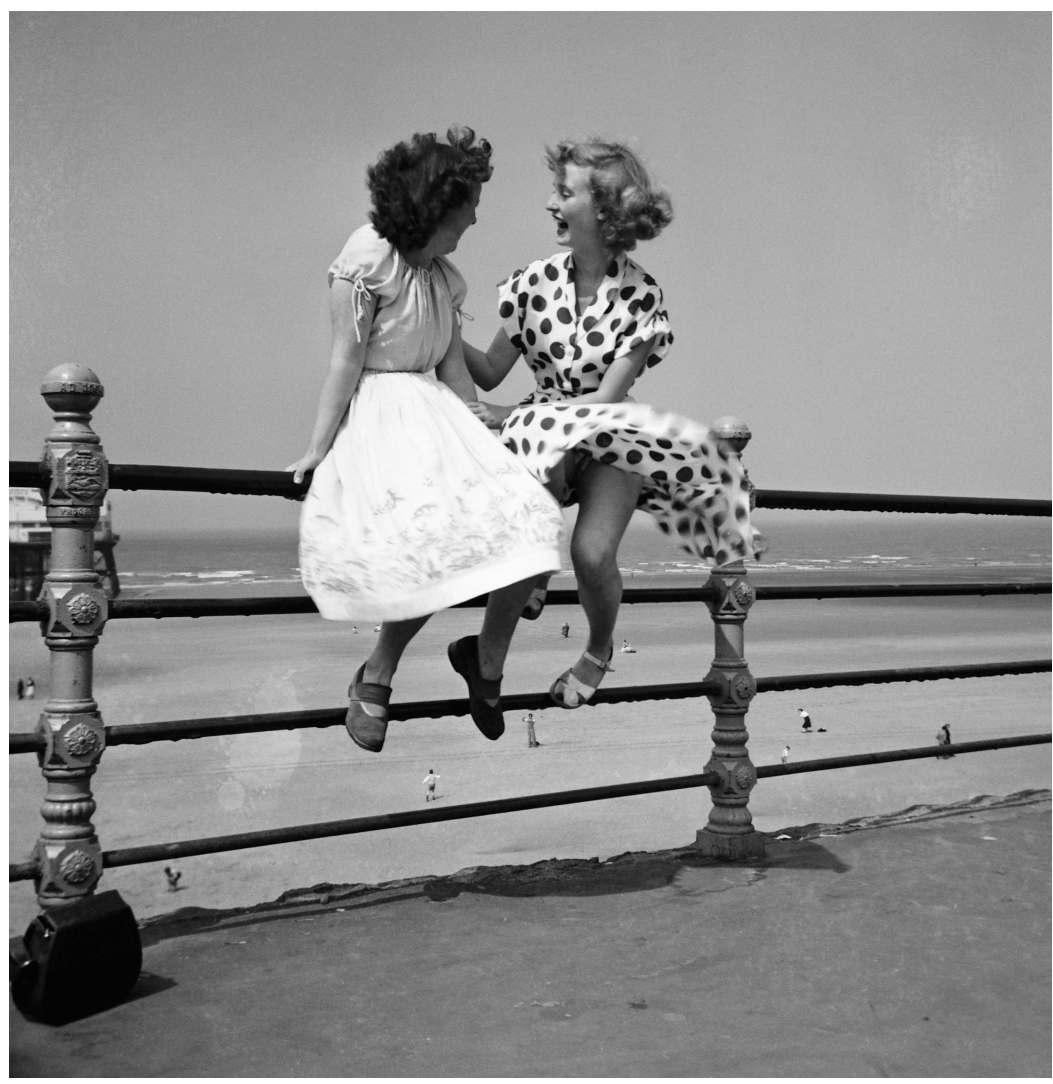

Figure 11. Bert Hardy, Maidens in Waiting, silverprint (July 1951). HU022100 RM (C) Bert Hardy/Hulton-Deutsch Collection/CORBIS

\section{Conclusion}

In "The Sexual Aberrations," the first essay in his Three Essays on the Theory of Sexuality, Freud asserted that "visual impressions remain the most frequent pathway along which libidinal excitation is aroused." While society may require the body to be concealed to a greater or lesser degree, he continued (and I quote this statement again): "curiosity seeks to complete the sexual object by revealing its hidden parts." However, if the normal scopophilic "instinct" should be restricted to the genitalia and become an end in itself, it becomes voyeurism, a perversion of the "normal" pleasure derived from looking. Exhibitionismtaking pleasure in being looked at-is the counterpart to voyeurism. ${ }^{35}$ The difference between scopophilia and voyeurism 
may be a matter of perception as much as reception. Joe di Maggio surely considered the spectators at the shoot in New York to be voyeurs — or, more likely, perverts - and Queneau evidently placed his "philosophers," with their "dilated eyes and blazing pupils," in a similar category.

In "Fetishism," a paper he published in 1927, Freud addressed a particular form of voyeurism when he linked footfetishism to the search for the missing female penis. For boys and for men, the woman's foot provided a means of access, enabling them to approach a woman's genitals from below, "from her legs up" (Freud 1991, p. 354). It is noteworthy that in Entr'acte, René Clair's Surrealist fantasy of 1924, the legs and underpants of a ballet dancer appear repeatedly, seen "di sotto in su" and gyrating convulsively, in what might almost be a textbook illustration of this fetish. ${ }^{36}$

In varying degrees and forms, the present study has been concerned with a form of scopophilia- a voyeurism that seeks to glimpse from below the hidden and most intimate parts of a woman. It is not important that what is revealed is the woman's underclothing rather than her sex, for the underwear is a surrogate for the woman's intimate parts-fetishes that, in Freud's words (1991, p. 354), "crystallize the moment of undressing." However, if the dancer's legs and panties seem distinctly Freudian in Entre'acte, in The Woman in Red, which belongs to a different era with different standards of decorum, they appear directed at a "normal" scopophilic viewer rather than a hardened voyeur.

Marilyn Monroe's portrayal of The Girl in The Seven Year Itch therefore defines and completes one tradition while initiating another. It is important, however, to underline that these traditions comprise several overlapping strands. First, there are pre-photographic traditions in literature and in the visual arts. Next, there is the cinematic tradition of The Blue Angel, "IT" and other films, together with their antecedents in popular entertainment—erotic postcards, amusement parks, cabaret and department stores. There is also a literary tradition that runs parallel to the cinema and its sources. It is noteworthy, for instance, that Joyce's Gerty MacDowell performs a "revealment" 
of herself to the accompaniment of a fireworks display. Likewise, Queneau's "salacity" is staged in Uni-Park, a French counterpart to Coney Island. Finally, there are twin photographic traditions. The earlier of these, which is exemplified by Kurt Hutton's and Bert Hardy's photographs, explores parallel subjects from the same vernacular culture. The other is inspired directly by The Seven Year Itch.

Notwithstanding this intermingling of media, it is apparent that there are also different degrees of "connection" within the trope and that parallels between literature and film are ultimately more convincing than those between film and photography. Moving pictures and the cinema are in harmony with the intimate connection Barthes drew between time- "intermittence"and the erotic. By contrast, still photography-and instantaneous photography most particularly_captures the moment and makes appearance permanent. In short, while moving pictures and writing can convey "appearance-as-disappearance," photography must record one or the other. It appears that Queneau recognized this distinction, for he made clear in Pierrot Mon Ami that his panoptic "philosophers" were intent on prolonging the "appearance" and delaying "disappearance." To this end, "in convulsive expectation, ... . with dilated eyes and blazing pupils," they "utilize[d] their visual capacities to the maximum of their output, each one demanding from the functioning of this sense, clarity, rapidity, perspicacity, photographicity [italics mine]. ${ }^{.37}$

University of St Andrews

\section{NOTES}

1. Several friends and colleagues have contributed to this study. Jan Baetens made me aware of Thomas Edison's What Happened on Twenty-third Street, New York City and Raymond Queneau's Pierrot mon ami and encouraged me to pursue this project. One of the anonymous readers for Cinémas kindly directed me to René Clair's Entr'acte and to Dorothy Arzner's Dance, Girl, Dance. At St Andrews Natalie Adamson introduced me to Émile Zola's $A u$ bonheur des dames, Annette Carruthers directed me to Edward Burne-Jones's letters to Katie Lewis, Calum Colvin told me about Anaiis Nin's Delta of Venus, Christine Linnell pointed me in the direction of Christian Dior, Tom Normand recommended James Joyce's Ulysses and Gustavo San Román suggested I see Gene Wilder's The Woman in Red. An earlier version of my paper was presented in the Forum on Gender and Sexuality at the University of St 
Andrews. I am grateful to participants in that seminar for their observations. Thanks also to Paul Barolsky, Roger Crum, Peggy Ann Kusnerz, Margaret Hall, Christina Lodder and Marianne Smith.

2. The type of full skirt worn by Monroe was introduced in 1948 and remained popular for much of the 1950s when they were sometimes known as "Poodle Skirts." A friend who was convent-educated in England informs me that she and her classmates were not allowed to wear patent leather shoes with this type of dress. It appears that her teachers were afraid that rapacious young men might catch a glimpse of the girls' knickers reflected in their shoes.

3. Stafford-Clark (1969, p. 99), defines exhibitionism as the "mirror image" of voyeurism.

4. See Nagel 2002 (pp. 3-26). The difference between reticence and revelation can be subtle. In David O. Selznick's adaptation of Gone With The Wind, for instance, we discover that antebellum belles were expected to keep their breasts hidden during daytime. "Miss Scarlett," admonishes Mammy, while dressing Scarlett O'Hara for the barbecue at Twelve Oaks, "You know you can't show your bosom 'fore three o'clock." Paradoxically, what would have been vulgar at mid-day became de rigueur at the evening ball. Jean-Honoré Fragonard's The Swing, painted in 1767, encapsulated for the mid-eighteenth century the erotic nature of female concealment and exposure. Madame Alvarez put it succinctly in Gigi: "Drawers are one thing, decorum is another." See Colette 1995 (p. 2).

5. For an account of the problems Axelrod and Wilder had to deal with when writing the screenplay for the film, see the AMC BACKSTORY ${ }^{\circledR}$ in the Marilyn Monroe Diamond Collection DVD of The Seven Year Itch.

6. Edgar Degas employed a similar framing device in his paintings of the ballet, where the theatre curtain sometimes cuts off all but the legs of the dancers. This gives the viewer the impression he is seeing something that is unauthorized-another kind of "appearance-as-disappearance."

7. A similar billboard decorated Grauman's Chinese Theater in Hollywood when the film opened there. See the photograph by Philip Gendreau, Grauman's Chinese Theater Showing "The Seven Year Itch," 1955 (BE029826 RM (C) Bettmann/ CORBIS).

8. This photograph can be seen at <http://www.artexpression.com/byimage/ NIMKN428.htm>.

9. Simmons's photograph can also be seen at <http://www.clickersandflickers.org/ museum006.htm>.

10. These photographs can be seen at <http://membres.lycos.fr/morimura/actress/ ym_marilyn03.jpg $>$ and <http://membres.lycos.fr/morimura/actress/ym_marilyn04. jpg>.

11. A delightfully vulgar variation on the theme is to be found in a brief sketch by the late Benny Hill in which he displayed his trademark leer while sneaking a lecherous peek under the frilly shade of a table lamp.

12. See Clark 2000 (pp. 80-87).

13. Sontag (2001, pp. 64-65), suggests that Barthes's writing "has some of the specific traits associated with the style of a late moment in culture- one that presumes an endless discourse anterior to itself, that presumes intellectual sophistication."

14. I am indebted to Elderfield (1994, pp. 65-95) for this idea.

15. See Nin 1977 (pp. 168-214). Earlier in "The Basque and Bijou," in a notable reversal of gender roles, Nin developed an erotic fantasy inspired by a parade in Paris of Scots soldiers in kilts: 
Maman was thinking: Each time the sporran swings, and the skirt swings, why, the other hangings must swing too. And her old heart was moved. Swing. Swing. . . . She was already moved enough by the swing of the pendants when the man at the bar added: "And do you know, they wear nothing underneath."

They wore nothing underneath! These sturdy men, such upright, lusty men! Heads high, strong naked legs and skirts-why it made them as vulnerable as a woman. Big lusty men, tempting as a woman and naked underneath. Maman wanted to be turned into a cobblestone, to be stepped on, but to be allowed to look under the short skirt at the hidden "sporran" swinging with each step. Maman felt congested. The bar was too hot. She needed air.

Nin's fantasy was recently fused with the image from The Seven Year Itch in a photograph promoting "Tartan Day" in New York (The New York Times, 28 March 2004, p. 21).

16. See Spira 2001 (pp. 182-195). In sixteenth-century Venice, there was already a market for prints depicting courtesans whose dresses could be opened to reveal their pantaloons.

17. It is perhaps noteworthy that Ralph Bellamy appeared in both films, playing Lucy's beau in The Awful Truth and the high-minded dance promoter Steve Adams in Dance, Girl, Dance.

18. It is perhaps worth mentioning that Elinor Glyn's sister, the British couturière Lucile, claimed to have invented the brassière. See Tobin 2000 (pp. 30 and 36).

19. Émile Zola in $A u$ Bonheur des dames likewise focused upon the erotics of consumerism, dwelling particularly on the sexual suggestiveness of the women's lingerie department. In fact, Denise Baudu in Au Bonheur des dames might be a prototype for Betty Lou Spence.

20. Library of Congress Motion Picture, Broadcasting and Recorded Sound Division, Washington, D.C., catalogue number 9693.

21. Ibid., call number FEB 9830.

22. See Didi-Huberman 2004.

23. In The Seven Year Itch Wilder's burlesque of Burt Lancaster and Deborah Kerr's famous embrace on the beach in From Here to Eternity makes clear his liking for "anterior discourses."

24. The passage is from a letter of 6 May 1874 to Joan Agnew Severn. Ruskin worked assiduously over a period of fourteen days in May 1874 on scaffolding erected for him in the chapel to produce a meticulous, life-size watercolour copy of this figure. See Clegg and Tucker 1992 (p. XIII). In "A Note on Botticelli's 'Zipporah,"” Ruskin (1906, pp. 478-479) described his drawing as "as nearly a facsimile as I could make it."

25. See Freud 1991 (pp. 69-70, 81, 84, 109-113, 120).

26. Hilton (1977, p. 276) suggests that Ruskin had hoped to make Rose jealous by confessing his infatuation with Zipporah. In Du côté de chez Swann, the first volume of $\grave{A}$ la recherche du temps perdu, first published in 1913, Marcel Proust introduced Zipporah as an "anticipatory and rejuvenating allusion" to Swann's lover, the demimondaine Odette de Crécy. The narrator explains that Swann admired Zipporah because of her resemblance to Odette de Crécy and, reciprocally, was attracted to Odette because of her likeness to Zipporah. See Proust 1981 (pp. 242-246).

27. See Weinberg 1987. Some twenty years later the erotic nature of the loose, flowing dresses and light, dancing steps of Botticelli's young women would also seduce Aby Warburg. In 1893 Warburg published his first study of Botticelli's Birth of Venus and Primavera, two paintings in which the wind god Zephyr plays a

The Subway Grate Scene in The Seven Year Itch: "The Staging of an Appearance-As-Disappearance" 
significant role, and throughout the 1890s he continued to focus upon the "Nympha" type and, more broadly, on the expressive functions of drapery in motion in the Florentine Quattrocento. See Gombrich 1986 (pp. 43-66 and 105-127) and Michaud 2004 (pp. 67-90). It is interesting that Michaud links Warburg's interest in the representation of figures in movement to an "aesthetic of movement" that was expressed at the end of the nineteenth century by chrono-photography, early cinema and dance.

28. See Christian 1988 (pp. 66-78).

29. This group of letters was excluded from the first publication of Burne-Jones's letters to Katie, presumably because they were considered to be too risqué.

30. See Joyce 2000 (pp. 449-499).

31. Joyce surely saw Bernini's Ecstasy of St Teresa when he lived in Rome. Almost seventy-five years after the publication of Ulysses, Roddy Doyle, another Dubliner, returned to the preoccupation with women's undergarments in two passages in his 1996 novel The Woman Who Walked Into Doors. Recalling her first experience of "going" with a boy, Paula Spencer reminisces: "Stephen Rooney was thirteen and dead nice but he was ugly as sin. God love him. Saying hello to Stephen Rooney when there was anyone around to hear you was like having your skirt blown up and your knickers shown off to everyone; it was an instant redner and it lasted longer." Later, when Paula remembers how happy she and husband were when they were still courting, her knickers serve to illustrate the uninhibited nature of their affection and their mad attraction to each other. Rather than drinking champagne from Paula's slipper, Charlo ate chips out of her knickers. For the British perception of knickers as "naughty," see Carter 2000.

32. See Queneau 1988 (pp. 7-24). In the 1960s a popular circus act involved teaching a "volunteer" the basics of trick riding. This volunteer was female, of course, and had been planted in the audience. After placing her in a training harness, she would be turned upside down to display her legs and knickers. The climax of the act required her to lose her dress completely. This act has a parallel in a short film of an artiste disrobing on a trapeze, made by the Edison Manufacturing Co. in 1901 (Library of Congress Motion Picture, Broadcasting and Recorded Sound Division, Washington, D.C., catalogue no. 5309).

33. For this photograph, see Hopkinson 1970 (p. 31).

34. See Hardy 1985 (pp. 140-141 and 154). In Plexus, which he published in 1953, Henry Miller wrote of Renée Tietjen: "she was leaning on the iron fence behind the gate and the wind molded her thin dress about her limbs. ... Now and then the wind lifted her skirt and we gasped when we caught sight of the milky flesh above her knees."

35. See Freud 1991 (pp. 69-70). Freud returned to these themes in "Infantile Sexuality" (pp. 109-113, 120), the second essay in his Three Essays. He observed that young children take pleasure in exposing their bodies and may also be interested in the genitals of their playmates. In short, scopophilia can appear spontaneously among children.

36. René Clair made this film with Francis Picabia and Erik Satie to introduce and fill the interval between the acts of Picabia's ballet Relâche, which was first performed in 1924 at the Théâtre des Champs-Elysées in Paris. In a later scene in the film, at the beginning of a funeral procession in which the hearse is drawn by a camel, the dresses of the female mourners billow in a strong the wind in yet another anticipation of the subway scene. See Clair 1970.

37. Queneau 1988 (pp. 10-11). 


\section{BIBLIOGRAPHICAL REFERENCES}

Axelrod 1953: George Axelrod, The Seven Year Itch: A Romantic Comedy, New York, Random House, 1953.

Barthes 1975: Roland Barthes, The Pleasure of the Text, New York, Hill and Wang, 1975.

Carter 2000: Angela Carter, "If the Nude Is Rude, Why Are Knickers Naughty?," in Inside Out: Underwear and Style in the UK, London, Black Dog Publishing for The British Council, 2000, pp. 28-33.

Clark 2000: Judith Clark, "Q Form," in Inside Out: Underwear and Style in the UK, London, Black Dog Publishing for The British Council, 2000, pp. 80-87.

Christian 1988: Letters to Katie from Edward Burne-Jones, London, British Museum Publications, 1988.

Clair 1970: René Clair, Entr'actelÀ nous la liberté, New York, Simon and Schuster, 1970.

Clegg and Tucker 1992: Jeanne Clegg and Paul Tucker, Ruskin and Tuscany, London, Ruskin Gallery, 1992.

Colette 1995: Colette, Gigi, Harmondsworth, Penguin Books, 1995.

Didi-Huberman 2004: Georges Didi-Huberman, "Knowledge: Movement (The Man Who Spoke to Butterflies)," in Philippe-Alain Michaud, Aby Warburg and the Image in Motion, New York, Zone Books, 2004, pp. 7-19.

Elderfield 1994: John Elderfield, "The Precursor," in The Museum of Modern Art at Mid-Century: At Home and Abroad, New York, The Museum of Modern Art, 1994.

Eliot 1920: T. S. Eliot, "Tradition and the Individual Talent," The Sacred Wood: Essays on Poetry and Criticism, London, Methuen \& Co. Ltd., 1920.

Freud 1991: Sigmund Freud, On Sexuality: Three Essays on the Theory of Sexuality and Other Works, Harmondsworth, Penguin Books, 1977.

Gombrich 1986: E. H. Gombrich, Aby Warburg: An Intellectual Biography, Oxford, Oxford University Press, 1986.

Hardy 1985: Bert Hardy, Bert Hardy: My Life, London/Bedford, G. Fraser, 1985.

Hilton 1977: Tim Hilton, John Ruskin: The Later Years, New Haven/London, Yale University Press, 2000.

Hopkinson 1970: Tom Hopkinson (ed.), Picture Post 1938-50, London, Allen Lane, 1970.

Joyce 2000: James Joyce, Ulysses, Harmondsworth, Penguin Books, 2000.

Michaud 2004: Philippe-Alain Michaud, Aby Warburg and the Image in Motion, New York, Zone Books, 2004.

Nagel 2002: Thomas Nagel, "Concealment and Exposure," in Concealment and Exposure and Other Essays, Oxford/New York, Oxford University Press, 2002.

Nin 1977: Anaïs Nin, Delta of Venus, New York, Harcourt, 1977.

Proust 1981: Marcel Proust, Swann's Way, New York, Penguin Books, 1981.

Queneau 1988: Raymond Queneau, Pierrot Mon Ami, Normal, Dalkey Archive Press, 1988.

Ruskin 1906: John Ruskin, "A Note on Botticelli's 'Zipporah,”' in E. T. Cook and Alexander Wedderburn (eds), Val d'Arno: The Works of John Ruskin, London, Allen, 1906.

Sontag 2001: Susan Sontag, "Writing Itself: On Roland Barthes," in Where the Stress Falls, New York, Farrar, Straus and Giroux, 2001.

The Subway Grate Scene in The Seven Year Itch: "The Staging of an Appearance-As-Disappearance" 
Spira and Lothrop 2001: S. F. Spira, Eaton S. Lothrop, Jr. and Jonathan B. Spira, The History of Photography As Seen through the Spira Collection, New York, Aperture, 2001.

Stafford-Clark 1969: David Stafford-Clark, What Freud Really Said, Harmondsworth, Penguin Books, 1969.

Tobin 2000: Shelley Tobin, Inside Out: A Brief History of Underwear, London, The National Trust, 2000.

Weinberg 1987: Gail S. Weinberg, "Ruskin, Pater, and the Rediscovery of Botticelli," The Burlington Magazine, no. 129, 1987, pp. 25-27.

Zola 2001: Émile Zola, Au Bonheur des dames (The Ladies' Delight), Harmondsworth, Penguin Books, 2001. 